\title{
Reforms to strengthen Moral Education in Japan: a preliminary analysis of implementation in schools
}

\begin{abstract}
This study examines the role of educational practitioners in mediating the implementation of the 2015 reforms of moral education. The revision of the Fundamental Law of Education and further commitment to a nationalistic agenda by successive governments have paved the way for curriculum reforms that introduced the value of patriotism as an objective in the moral education curriculum. The reforms in 2015 reassigned moral education as a 'special subject' requiring both ministerial approval of textbooks and assessment. However, previous studies have focused almost exclusively on policy and curriculum analyses. Few studies have examined the school or classroom to understand practice as implemented. Challenging the assumption that these revised documents describe changes in practice, this study examines the early stages of the implementation of policy, which is invariably mediated by education practitioners 'enacting' policy. Despite the undeniable trend of central policy promoting a 'love of country' and efforts to increase state control of education, a stronger patriotism in moral education may not soon materialise in the classroom under the current pace of reform, though structural changes may have longer term potential to limit the autonomy of teachers to mediate policy implementation. The results contribute to our understanding of how these reforms are being implemented, and more broadly how teachers in Japan enact reform 'on the ground'.
\end{abstract}

Keywords: Education reform; moral education; patriotism; nationalism; Japanese education; new institutional analysis; policy implementation.

Acknowledgement: This research was supported by the Winston Churchill Memorial Trust through the award of a Churchill Travelling Fellowship (2015) to the author. 


\section{Reforms to strengthen Moral Education in Japan: a preliminary analysis of implementation in schools}

\section{$\underline{\text { Introduction }}$}

Moral education is an important aspect of education in Japan, and receives prominence in the curriculum (Khan, 1997; Wray, 2000). Likewise, teachers are committed to moral development (see below) as a part of 'educating the whole person' (Tsuneyoshi, 2001; MEXT, 2008). Over the decades following its reestablishment post-Occupation, moral education practice has become increasingly child-centred and focused on fostering independence and interdependence (Hoffman, 1999; Anzai, 2015).

More recently, however, a revision to the Fundamental Law of Education (FLE, kyōiku kihon $h \bar{o})$ in 2006 established patriotism as a stated aim of the education system, driven by the Liberal Democrat Party (LDP) and enacted shortly after the 2006 LDP-Komeito coalition government was formed. The wording of the FLE entered policy documents, the curriculum and curriculum guidance. Finally, in 2015, The Ministry of Education (monbukagakushō; MEXT) adopted recommendations of the Council for Rebuilding Education, established in the Cabinet Office, to reform the structure and content of moral education in the curriculum. These reforms reallocate moral education as a 'special subject' of the curriculum rather than 'classtime', thus newly requiring assessment and ministerial textbook approval. These changes emerge against a backdrop of the current government's drive in patriotic, or nationalistic, policy.

This study provides a preliminary analysis of the implementation of these reforms in schools using document analysis and interview and observation data collected with educators in the months following the announcement of the reform. Although anticipated some years prior, the reforms were announced in March 2015, detailed in July 2015, and required implementation in the years leading up to $2018 / 19$.

Previous studies have utilised various methods to research moral education. The most frequent include analyses of national policy debates (Wray, 2000; Roesgaard, 2011), revisions to the Fundamental Law of Education (Roesgaard, 2011), the curriculum (Hoffman, 1999) and content of coursebooks (Anzai, 2015; Kaizuka, 2009, Matsuno, 1997). These documents are continually in discussion as constituent parts of the debate on moral education. However, few studies in moral education have examined the school or classroom ethnographically to understand practice as enacted. Any assumption that these revised documents describe changes in practice in a simple way is unfounded. As Anzai suggests:

"Whilst Japanese education is now regarded both inside and outside Japan as pressing for a greater emphasis on patriotism and nationalism, there is still insufficient empirical inquiry into the issue of whether such an inclination is actually manifested in this moral education plan" (2015, p. 438).

It is now widely recognised that "the individuals relied upon to implement reform initiatives modify these policies" in response to the institutional environment (Bjork, 2016, p. 35). Ball (1994, p. 19) utilises the term 'enactment' of policy, rather than implementation, to emphasise the agency of professional, such as teachers and other educators, who act within 
circumstances created by policy change to mediate its implementation. Furthermore, policy drafting is "not always based on first-hand knowledge of conditions in schools" (Bjork, 2016, p. 34). Nonetheless, research on moral education has tended to privilege the policy envisaged. Situated research in schools can provide data to understand the enactment of policy.

This research contributes to scholarly understanding of contemporary and future moral education not only in examining a current reform agenda briefly, but also analysing data collected at schools where education is practiced and reform is implemented. It departs from previous studies on moral education, which tend to overlook how teachers enact reform 'on the ground'. It aims to describe the current and envisaged changes in practice resulting from these reforms. More broadly, the study contributes theoretical insight into how teachers in Japan engage with reform implementation under conditions different from previous reforms (such as yutori kyōiku) that have been studied ethnographically. The study is preliminary in exploring how educators position themselves in relation to the policy at an early stage.

\section{Policy and curriculum: a documentary overview}

The curriculum has gradually tended to further emphasise moral education since the 1989 curriculum. Moral education is currently enshrined as one of three dimensions of education: heart, body and intellect (MEXT, 2008) aiming to cultivate a 'zest for living' (ikiru chikara). Moral education is envisaged as practice infused throughout the curriculum:

"The aims [of moral education] should be taken into account when planning all lesson content and School Activities to enrich it through deeply integrated, structured and developmental supervision to additionally deepen thinking on autonomous living and consciousness of moral values to underpin application in real life" (MEXT, 2008, ch3). These pre-2015 curricula also provided for moral education classtime (dōtoku-no jikan) which is devoted to moral education (ibid, ch3 s3). ${ }^{1}$ Though the history of moral education is not recounted here,$^{2}$ concern for its potential for instilling nationalistic values has remained a perennial issue since the reinstatement of moral education classtime in 1958. Partly for this reason, moral education classtime coursebooks have not required ministerial approval, which has long been required for all areas of the curriculum designated as a subject. ${ }^{3}$

A significant turning point in education policy arrived in 2006 when the Fundamental Law of Education (FLE) was revised for the first time since its enactment in 1947. The National Commission on Education Reform (Kyōiku kaikaku kokumin kaigi) was established in 2000 to recommend revisions to the FLE, which successive LDP cabinets have seen to overly emphasise 'Western' values, those seen to have been imported along with learning about Western technology during the catch-up period and the Occupation under which the original law was enacted, at the expense of 'Japanese' values (Yamazumi, 1986; Okada, 2002). The revised law established as aims of education "respect for culture and traditions and love for

\footnotetext{
${ }^{1}$ Classtime is allocated to 'domains' of study, which are not designated 'subjects'.

2 Excellent document analyses of moral education are readily available in the literature, summarised from various angles. See Kaizuka (2009) and Roesgaard (2016) for well-focused examples.

3 Throughout this article, I use 'textbook' to translate kyōkasho, which require ministerial approval; and 'coursebook' to translate fukudokuhon, which provide supplementary content and do not require approval. Until now, moral education has only used the latter, but with the new curriculum changes, it will use the former.
} 
their nation and region that nurtured them, along with respect for other countries and attitudes contributing to the peace and development of the international community" (FLE 2006). This was seen to hold implications for moral education classtime amongst other school activities (Anzai, 2015; Okada, 2002). Current Prime Minister Shinzo Abe was instrumental in its drafting and passage to the House, assuming the office for his first term as prime minister short before the revision was passed. The following year, the wording of the FLE was incorporated by MEXT into the new curriculum under moral education, along with other changes (MEXT, 2008).

The revision caused widespread concern in the teaching community and in the national press debating education becoming an oppressive instrument of the state (see Anzai, 2015, p. 437-8 for a review). These views are often expressed, at times hyperbolically, as returning to the imperialist indoctrination which is seen to characterise the pre-1945 period during which Japan's military aggression escalated toward the Pacific War. The culturally conservative 'right' is seen to push for patriotic revision against resistance from 'progressives', including anti-militarist citizens, the left-leaning press and unions such as Japan Teachers Union (Nikkyōsō). However, there are multifarious stakeholders with assorted positions (Roesgaard, 2011) and no wholly united fronts (Takayama, 2011).

The current Prime Minister Shinzo Abe is culturally conservative (Abe, 2006). The current government is advocating revision to the constitution to provide for a standing army and fewer restrictions on military engagement. The current prime minister and the education secretary re-appointed by Abe are also affiliated with Nippon Kaigi, a culturally conservative group that argues strongly against 'masochistically' (jigyaku-teki) teaching 'dark moments' in Japanese history. They frame Japanese aggression during the pre-1945 period as a regrettable but not unreasonable response to the international politic of the time (Nippon Kaigi, 2016). The amendment to the FLE, and the curriculum changes it prompted, are therefore considered within the context of the current cabinet's larger political moves and influences. To this end, Takayama has argued (e.g. 2011) that changes to the FLE reflect some aspects of the 1890 Imperial Rescript on Education as evidence of a conservative outlook.

In 2015, MEXT adopted recommendations of the Council for Rebuilding Education (Kyōiku saisei kaigi, later the Kyōiku saisei jikkō kaigi) to reform the structure and content of moral education in the curriculum. The Council was established as an advisory committee to the cabinet, modelled after the National Commission on Education Reform (Kyōiku kaikaku kokumin kaigi, 2000) and Ad Hoc Council on Education (Rinji kyōiku shingikai, 1984). This is significant in bypassing or pressuring the Ministry of Education's Central Committee on Education (Chūō kyōiku shingikai). Although anticipated some years earlier, the Ministry of Education announced in March 2015 that moral education classtime (dōtoku-no jikan) would be reassigned as a special subject (tokubetsu kyōka), to take effect in the years leading up to $2018 / 19$ (MEXT, 2015a). Schools are free to implement changes earlier, which may be encouraged by local education offices, with a requirement for elementary schools to implement by April 2018 and junior high schools by April 2019.

The reforms amended the content of moral education slightly, continuing to include patriotic values. The new status of moral education as a subject will entail two substantive changes. Textbooks will be subject to ministerial approval, and the subject will entail assessment. The 
moral education subject assessment will assess activities potentially outside this subject's classtime. This explains its status as a 'special subject' as opposed to a general subject. These changes emerge against a backdrop of a drive in patriotic, or nationalistic, policies by of successive governments, with the Abe administrations chief amongst them.

\section{$\underline{\text { Implementation in practice: institutional beliefs and practices }}$}

The policy and curriculum aspects of this reform to moral education were outlined above. As explained above, however, practice is complex and enacted through the circumstances created by policy. Although teachers adhere to requirements, the notion that employees are technicians acting in rational self-interest is not tenable (Katsuno, 2016, p. 41). Anzai's (2015) content analysis demonstrates that the revision of the FLE and 2008 changes to curriculum content has not led to significant change in the patriotic content of textbooks. Anzai's examination of textbook content identified 'appreciation of life', 'modesty and selfrestraint' and 'faithfulness and friendship' as the most frequent values portrayed. These were followed by 'sympathy and kindness', 'politeness and manners' and 'love for family'. However, the relative importance afforded to these values by teachers differ in practice. Even where ministerial approval is required for history textbooks, the relationship between policy and textbook content is not linear, and may be influenced more by demand through the prefectural adoption process than ministerial requirements (Cave, 2013). Policy implementation is mediated by textbooks, and also educators such as teachers, principals and education administrators.

Educators are not only important contributors to this debate, but also have agency in mediating the implementation of policy. Teachers exercise great autonomy in selecting, framing and augmenting content from textbooks - they use the content creatively (Cave, 2016). However, the processes by which teachers and educators mediate policy implementation are broader. Current research is analyses these processes to understand how educators operate as active agents in the implementation of policy (Cave, 2016; Bjork, 2016).

Drawing on Lipsky's (1983) notion of the 'street level bureaucrat', McLaughlin notes that 'a policy is transformed as individual [teachers] interpret and respond to it. What is actually delivered or provided under the aegis of a policy depends finally on the individual at the end of the line' (1987, p. 174). Lipsky and McLaughlin suggest that, whilst considering policy, educators make decisions in and based on shared understandings of professional practice. Moreover, individual actors are increasingly considered within their social institutional context. Institutions, by their nature, incorporate both horizontal and vertical relationships in relative isolation from outsiders, and incorporate systematic processes of learning within the professional domain (see Cave, 2016, pp. 177-182, 220-227). The domain of education includes aspects of pedagogy and, perhaps more importantly, includes practices and beliefs on what should happen in the classroom and school, which are socially constructed in no small part through institutional interactions.

In later work, Taylor (2007) has noted that Lipsky's preceded the wide adoption of New Public Management in the organisation of schools in the USA and the UK. Taylor argues that the preconditions for Lipsky's theory no longer hold in the UK education context, and thus 
teacher autonomy to mediate reform is limited by the application of accountability tools. These limitations are additionally considered in interpreting the data in this paper.

Turning to the Japanese context, Cave (2016) and Bjork (2016) have drawn upon ethnographic data to detail the means by which educators appropriated reforms aiming to realise a series of goals grouped under the nexus 'relaxed education' (yutori kyōiku). As Cave summarises, 'to a significant extent, the content of the program amounted to existing activities' (2016, p. 221). The present study likewise draws on ethnographic methods, particularly classroom observations and interviews with educators, as outlined in the following section. As Bjork notes, "[s]tudying reform in an "embedded context" can overcome the limitations of rational choice models that see positivist reductionist analyses of policy" (2016). Data are analysed as institutional beliefs and practices to understand current and future practice in moral education in light of current reforms. The concluding section considers the possible outcomes of these reforms in reference to previous work.

Educators' perspectives on the importance of educating the whole person have been detailed in a series of ethnographic studies (Cave, 2007), though largely in the preschool context (Hendry, 1986; Peak, 1993; Lewis, 1995). Very recent research has examined the values taught in contemporary moral education practice. A previous analysis (Bamkin, 2016) with participants largely overlapping with the current dataset during the same period of fieldwork found that the majority of teachers interviewed placed 'consideration of others' (omoiyari, similar to sympathy and kindness) distinctly as the most important value. This was followed by perseverance (ganbaru), which did not feature as a category in Anzai's study. Finally, a significant minority of participants identified 'comportment and manners' as important, which unfortunately does not differentiate between Anzai's categories of 'manners and politeness' and 'public manners and civility'.

This demonstrates that the objectives of moral education as implemented by teachers in the classroom depart from coursebook foci, despite the clear overlap. Teachers utilised moral education coursebooks 'creatively' to accord with their beliefs on what values are important. The present study focuses on educators' perspectives on the current reforms in the context of policy and curriculum. Interestingly, patriotism is raised by teachers in response to general inquiries about the curriculum reforms. Likewise, the themes of ministerial approval of textbooks and assessment emerge in relation to nationalism and teacher autonomy. These topics have an important relationship in the accounts of educators and teachers.

\section{Method}

The data were collected from individual and small group interviews with over 80 education practitioners and 50 observations of teaching in and around 16 schools in five locations in Japan. The schools comprised nine elementary schools, six junior high schools and one combined elementary and junior high school. All schools were public and maintained at the municipal level (shiritsu or kuritsu). Education practitioners included 37 teachers ${ }^{4}, 11$ principals, 10 vice-principals (fuku-kōchō or kyōtō) and 14 Education Officers (at kyōikuchō,

\footnotetext{
${ }^{4}$ Principals and vice-principals were not included in the count of teachers, despite vice-principals often undertaking some regular teaching. The count of practitioners with regular classroom teaching is 47 .
} 
kyōikuiinkai-jimukyoku, or equivalents) or members of the Board of Education (kyōikuiinkai) ${ }^{5}$. Other informants undertake work in schools as: Ministry bureaucrats, retired headteachers, guest teachers or supervisors (shidō-kyōju) involved in teacher education. All informants progressed in their career from a teaching position, except for national-level bureaucrats and those interviewed as guest teachers. In addition to observation of formal lessons, other activities and observations within the school provided further insight. This article draws mainly on the interviews with active teaching staff, including subject leads, supported by other interviews and observations.

\begin{tabular}{|c|c|c|c|c|c|}
\hline Code & Description & $\begin{array}{l}z \\
\text { z) } \\
\overline{3} \\
\frac{0}{1} \\
0 \\
0 \\
0 \\
\frac{0}{0} \\
\frac{0}{\omega}\end{array}$ & 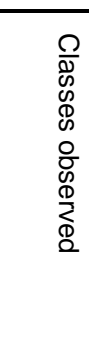 & 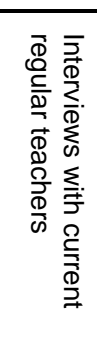 & 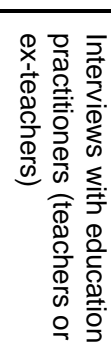 \\
\hline \multirow[t]{2}{*}{ ku-1 } & \multirow{2}{*}{$\begin{array}{l}\text { Central Tokyo ward. Largely residential with } \\
\text { reputation for high education provision. }\end{array}$} & $1 \mathrm{ES}$ & 18 & 2 & \multirow{2}{*}{$\begin{array}{c}23 \\
(21)\end{array}$} \\
\hline & & $1 \mathrm{EJC}$ & 11 & 15 & \\
\hline ku-2 & $\begin{array}{l}\text { Central Tokyo ward. Big business, government } \\
\text { offices, main transport hubs. }\end{array}$ & $2 \mathrm{ES}$ & 5 & 3 & $7(7)$ \\
\hline \multirow[t]{2}{*}{ shi-2 } & \multirow{2}{*}{ City in south-west Japan. } & $2 \mathrm{ES}$ & 4 & 4 & \multirow{2}{*}{$\begin{array}{c}12 \\
(11)\end{array}$} \\
\hline & & $1 \mathrm{JHS}$ & 4 & 3 & \\
\hline \multirow[t]{2}{*}{ shi-3 } & \multirow[t]{2}{*}{ City in central Japan with mainline rail station. } & $1 \mathrm{ES}$ & 2 & 2 & \multirow[t]{2}{*}{$12(9)$} \\
\hline & & $2 \mathrm{JHS}$ & 2 & 2 & \\
\hline \multirow[t]{2}{*}{ shi-4 } & \multirow[t]{2}{*}{ Small city in west Japan } & $3 \mathrm{ES}$ & 3 & 6 & \multirow{2}{*}{$\begin{array}{c}34 \\
(30)\end{array}$} \\
\hline & & $3 \mathrm{JHS}$ & 3 & 10 & \\
\hline Total & & 16 & 52 & 47 & $\begin{array}{c}88 \\
(78) \\
\end{array}$ \\
\hline
\end{tabular}

Visits to shi-2 and shi-4 were organised by the National Institute for Educational Policy Research (NIER) with the assistance of the Boards of Education. Visits in ku-1 and ku-2 were organised through personal contacts at the NIER with the assistance of school principals. Personal contacts provided visits to the City Education Office in ku-1. Visits in shi3 were organised through personal contacts with the assistance of the Prefecture Education Office, Community Centres and schools.

During earlier fieldwork, I spent more time observing in a small number of schools to become familiar with one site. In particular, an early visit to ku-1 comprised 19 observations and seven early interviews at a single site. ${ }^{6}$ Subsequent visits allowed deeper interviews drawing on familiarity with practice based on observations at previous sites. For example, toward the end of the research period in shi-4, I undertook 34 interviews at six sites, interviewing four out of the six teachers observed.

\footnotetext{
${ }^{5}$ The categories of Board of Education member and Education Officer often overlap, proportionally more so in rural areas because there are fewer staff in the Education Office.

${ }^{6}$ The figures in Table 1 aggregate data from two visits to ku-1.
} 
Whilst placed in schools and Education Offices, I was an outsider to the working group of teachers, but shared space within the wider community of educational practitioners. My outsider status made demands on good rapport, whilst a common understanding of school practice allowed identification with key issues. For the main part, I identified as a peripheral member (Adler and Adler, 1987), or observer-as-participant using Gold's (1958) classic continuum between observer and participant. Observations were used to support interviews, which provided the main sources of information. Interviews with members of Board of Education, Education Officers and headteachers were generally scheduled. Most roundtable discussions were scheduled, comprising between three and six participants with a headteacher present. Invitations to interview teachers were extended after observations, although busy teacher schedules limited opportunities to interview teachers observed. Where possible, these interviews were undertaken mainly during breaks. Documentary and policy documents were utilised to provide context and support the interpretation of participant data. The majority of data from teachers and headteachers are from elementary schools. However, similar results were found in the smaller set of data with junior high schools and the junior-high sections of combined school. Similarly, Education Officers and Board of Education members work with both levels of compulsory education.

Data were collected between May and July 2015. The Ministry of Education had announced the outline of amendments to the moral education curriculum, also reassigning it as a special subject, in March 2015. Therefore, this research was undertaken at a crucial point in time when most participants had heard of the revisions in principle but had not accessed specific plans on implementation. Further details were released in early-July 2015, but did not detail requirements for assessment. At the time of writing, it is still unclear how prescriptive or what form assessment of moral education will take, although some principles have been outlined. These were not discussed in interviews.

\section{Beliefs on moral education and nationalism.}

Initially, out of 21 interview responses detailing purposes or values in moral education, not one participant educator provided love of nation as a value important for moral education in Japan. The overwhelming majority of participants did not raise the topic of patriotism or 'love of nation' or country. Only one participant included 'feeling good things about Japan' seventh in a list of eight objectives. This finding is salient by its absence. Later in-school training sessions (kōnai kenshū) introducing the revisions were likewise salient by what was absent. Observations included three school supervisors in three regions (ku-2, shi-3, ku-1) presenting on the revisions to the curriculum. Not one of these mentioned love of nation or country. One supervisor explained 'the list of values has condensed the content under 4 headings, but there is little change'. These experienced educators who conduct in-service teacher education did not draw attention to patriotism.

Participants in this study were asked to comment on the curriculum changes in moral education, which was a current topic at the time. Half of participants opened with direct or oblique reference to nationalism as a purpose of the revisions, if not apparent as curriculum content. One teacher in shi-3 summarised:

"They are going to suggest assessment to make certain content more important, so teachers cannot ignore it. The reason is to promote nationalism (aikokushin), like if we are going to teach about the Senkaku islands." 
Teaching staff in all locations outside Tokyo, and to a lesser extent in Tokyo, expressed similarly strong beliefs in opposition to teaching patriotic values. Discussions on nationalism were also begun by principals in both one-to-one discussions and in the presence of teachers in group discussions. A headteacher in shi-4 suggested early in a group interview:

"Most teachers are against the amendments[...] Changing the content is not necessarily a bad thing, but there are problems."

This demonstrates similar strong beliefs, sometimes expressed as scepticism but more commonly as opposition to patriotism as an educational objective. The mention of nationalism (aikokushin) by these principals may have legitimised a discussion which could otherwise prompt caution in the presence of senior staff. However, it may further suggest that these principals sensed that other participants were poised to raise the subject. This could be suggestive of high consensus amongst education practitioners, in these group interviews if not more widely. These arguments against teaching patriotism are ideological. Normative statements expressed that patriotism 'should not be taught'. One participant considered how content on territories could be taught:

"I hold my opinions on the [Senkaku] island problem, Korea, China, etc., but moral education (dōtoku-no jikan) is not the place to discuss it. Perhaps Social Studies. But we cannot return to Fascism."

Nationalism was seen as the political driver for reform, which was seen to risk a move toward (or 'return to') militant ethnocentric nationalism.

These data demonstrate that personal and institutional beliefs create barriers to the implementation of this aspect of reform. Teachers tended to believe that reforms were motivated by the nationalist agenda of the current government which did not accord with institutional beliefs on the purpose of moral education. The apathy of teacher educator guidance from supervisors and opposition of principals reinforces resistance. Institutional processes of leadership reproduce this belief. The Senkaku territorial dispute was receiving media coverage at the time of the interviews. It is utilised as an example to illustrate the view that education should be protected from patriotism to avoid the ethnocentric nationalism that may result in widespread fascism. At first sight, this may seem overly cautious. However, there is also overlap in government publications.

The 2014 LDP manifesto commits to reform moral education and to promote more patriotic history textbooks under the same bullet point:

"make Japanese history compulsory at senior high school, establish moral education

as a special subject [...] apply the new criteria for [ministerial] textbook approval, enhancing the content relating to Japanese territories" (LDP, 2014, p. 21).

This wording is adopted from the more verbose 2012 manifesto which provided further explanation:

"The FLE was revised and the curriculum was revised accordingly. However, there are many history textbooks which provide biased and self-torturing views of Japanese history. Children should learn using textbooks that develop pride in Japanese culture and history" (LDP, 2012, p. 19).

The Senkaku islands were mentioned in a military context in Abe's second term inaugural speech (2012). Thus, education is viewed by the current government as a potential key to normalising a belief or ideology instrumental to the state in debates recognised as militarisable. Presented by the government as learning content on Japanese sovereignty, many educators saw the potential for an ideology of Japanese supremacy or aggression. 
The opposition to nationalism expressed concern about militarisation. On the other hand, observations revealed moral education as a site for reproducing notions of 'traditions'. The reproduction of traditions, such as crafts, ritual, stories and symbols, may facilitate ethnocentric nationalism if presented as timeless (reified) or necessarily superior to alternatives and as characterising of a particular group (essentialist mythologising). Strong association of tradition with the nation (geographical, ethnic or political) may be a means of promoting a love of nation.

Comportment and manners were identified by a significant minority of participants as one of the most important values learned in moral education. One observation comprised a fifth grade lesson aiming to develop perseverance (ganbaru) using the martial art Kendo as content. One pupil, who practices Kendo, had dressed in full Kendo costume and entered the class, leaving his practice sword at the front of the class, and bowed to the floor (zarei). Students had time to ask questions, and slowly began the reading about a fifth grade students describing his beginnings aged three, learning precise comportment in bowing and other etiquette; then anxiety facing an opponent for the first time; and development through years of Kendo training (reading: MEXT, 2014, p. 170-3). Students discussed questions posed by the teacher: "what customs have you seen?", "why are there customs in Kendo?", "why are these important in our lives?", "how would you feel facing an adult opponent?" Whilst discussing manners and development, the reading twice described the etiquette as beautiful (utsukushii), and the teacher reiterated that the practice of etiquette, respect and Kendo in general are 'important'. This was once phrased as "it is very important to Japanese people (nihonjin)". The reading concludes with the Kendo teacher explaining that it is important to always 'show humble respect (umayai, sonchō-suru)' to one's opponent. The teacher reframed this as kind consideration (omoiyari), but focuses the conclusion on perseverance, exemplifying the years athletes need to train for the Olympics, also a current topic at the time of observation. The students write 'what they have learned', as in most classes. About half wrote about respect, and just under half about perseverance and their own pursuits in sports.

The teacher who organised this lesson on Kendo did not see patriotism as an objective of the lesson or moral education in general. Although Kendo and associated etiquette were framed as important, the Japaneseness of Kendo was only alluded to once in passing. I observed only one lesson (shi-2) which framed values as particularly Japanese, reflecting on a scene from the successful period drama Yae-no sakura (NHK, 2013). The scene, set in the bakumatsu period (1850s), framed a moral dilemma in which a group of children are disturbed from playing and questioned by high-ranking retainer and need to decide whether to expose misbehaviour of a friend or cover up the truth, whilst the culprit is observing from a hiding place. The film was stopped at intervals to discuss how all characters might be feeling. In the end, the hidden culprit needs to explain herself to the officer whilst her brother is present as a member of the military retinue, creating a further social complex. The teacher clearly emphasised that aspects of the officer's speech in the film was taken from a 'real samurai code', which is still relevant today and that all Japanese should carry in their hearts. It is also important to note that the culprit and main character later exemplifying the samurai code is a female character. The period drama clip thus accommodates a contemporary notion of gender-equality. Whilst maintaining that the values included in the historic samurai 
code are important and traditional, the teacher accepts without mention its application to both genders.

Overall these observations did not reveal traditions presented as reified in many examples. At times, the importance placed on traditions 'to Japanese people' could be seen as moving toward essentialism, as in the Kendo example. Other examples were framed in a more contested context, such as the samurai example. 'Manners and comportment' was more often presented as necessary or healthy. For example, a teachers might explain that it 'naturally feels uneasy' harbouring a lie, or supervise the expression of gratitude without explanation (Bamkin, 2016). One headteacher who had emphasised the 'important tradition' of saying 'itadakimasu' (bon appétit) before eating clearly valued the practice. Nonetheless, he later explained that, although an important tradition, it has been adopted only during the Showa period, probably referring to the mid-twentieth century. Pedagogically, tradition can be a trope of convenience as well as a nationalising myth, which calls into questions its relationship to 'love of nation'.

Finally, the FLE revision added 'love of the region (kyōdo)'7 alongside 'love of nation'. However, this addition has received very little attention. Previous ethnographic research has found that 'localism' and even patriotic-like attitudes toward the locality have long been practiced in elementary education (Cave, 2007). For example, local studies in social studies lessons (ibid) centre on trade and expand to the national and international in higher school years. It is moreover plausible that this strong localism in both elementary and junior high schools may even go some way toward pre-empting nationalistic education. Education promoting love of the region does not present the people as separate from other localities. In this sense, it is not necessary ethnocentric. It tends to promote a focus on the locality within a framework of interdependence with surrounding regions. It may contribute to the building of a homelike feel for the childhood region connoted by the adult understanding of the land or country (kyōdo).

This situated research has questioned the assumption that education practice simply implements policy as intended. Data collected from education practitioners demonstrates some beliefs and practices which shape the implementation of policy. Although general discussion of moral education demonstrated that debates on patriotism are not a day-to-day concern for educators, ideological expressions of opposition emerged clearly from interviews that raised the current reforms. Educators see the reform as driven by nationalism.

Normative arguments saw related content, such as territorial disputes, as outside the correct domain of moral education. It seems difficult to imagine how educators will change content, if at all. Using textbooks 'creatively' may afford teachers to focus on areas other than patriotic content. Indeed the textbook content utilised in the above Kendo example is designated as content on 'love of nation', but the teacher observed refocused on the value of persistence. Teachers and school administrators mediate the implementation of policy, and may have the will to subvert policy promoting 'love of nation'.

\footnotetext{
7 Though the translation 'land' or 'country' is more common, my observations illustrated that kyōdo is represented in the classroom as places, images and practices of the local region. Likewise, the curriculum provides separately for learning national culture and regional (kyōdo) culture, for which a countrywide land would not fit.
} 


\section{$\underline{\text { Textbook adoption }}$}

Interview participants discussed content expected under current reforms to moral education. Examples provided focused on militaristic thought and territorial disputes. Furthermore, the current government has related moral education reform and the promotion of alternative textbooks. Nonetheless, participants did not appear to envisage the curriculum changes in content as likely to change their teaching. In this area, teachers may have confidence in their scope to use content 'creatively' to refocus or leave out patriotic content. This suggests that focusing on the requirement for ministerial approval may over-simplify the process of textbook adoption. This section discusses textbook adoption as a structural change that will be adopted in moral education in the years leading up to 2018/19.

Teachers felt a significant degree of autonomy in using textbooks creatively to bypass content that conflicts with beliefs and purposes they feel are important. This lends support to the analysis of teachers, in this case, as street level bureaucrats. Despite the purported strengthening of moral education, this may alternatively be understood as a lack of policy to enforce requirements. Taylor, who argues for a trend of declining levels of autonomy amongst teachers in the UK, theorises that accountability tools are required to reduce autonomy. For example, in his (2007) study, respondents teaching 'core' curriculum subjects felt a further strengthening of the state over their work and thus reduced autonomy.

As an alternative, the extent to which ministerial approval represents real structural change for classroom teachers can be questioned. An analysis by Cave (2013) in the context of junior high schools discussed the politics of adopting patriotic textbooks for the subject of history over the preceding two decades. Since publication in 2001, overtly revisionist history textbooks have not been popular, with only $1.7 \%$ market share by 2009 , two-thirds of which was in Yokohama (ibid, p. 544). However, other history textbook publishers also reduced critical content portraying 'dark moments' in Japanese history in the years after 2001. Cave explains this as pressure created by local preferences during the selection and adoption process for partially market-driven textbook publishers.

Partly as a result of campaigns by the nationalistic Association for New History Textbooks (Atarashii rekishi kyōkasho-wo tsukuru kai), boards of education were encouraged to appraise and select textbooks, rather than following the recommendations of textbook advisors drawn from education practitioners and experts. Although advisors continued to appraise textbooks, about one third of prefectures, including the Tokyo Metropolitan area, had ceased to receive recommendations of specific textbooks by 2009. Boards of education are appointed by the local mayor, with agreement of the local assembly. Cave suggests that:

"since local mayors and assemblies have shown a strong tendency to be politically conservative in Japan, textbook selection by local boards of education themselves would be likely to result in more conservative textbook selection choices" (2013, p. 564).

The textbook advisors had had provided input from education practitioners, but this is now eroded. This reduces the influence of education practitioners in textbook appraisals. ${ }^{8}$

\footnotetext{
${ }^{8}$ As an aside not discussed here, Cave additionally offers an insightful analysis against the assumption that education experts are necessarily best placed to make educational decisions,
} 
These structural changes to the textbook adoption process were technically prefectural changes within the existing law, but are supported by legislative and executive trends toward decentralisation which reduces the role of ministries in selection issues (Muta, 2006; Cave, 2013; Nakayasu, 2016). However, the reallocation of moral education as a special subject requires that moral education textbooks adhere to the ministerial approval system for the first time. This does not mean that coursebooks did not exist for moral education. Perhaps because coursebooks published by MEXT and private publishers already include content designated under the learning outcomes for 'love of nation', teachers perceive little change.

\section{Assessing moral education}

Under the 2015 reforms, moral education will become a 'special subject' rather than 'classtime'. In addition to the requirement for textbook approval, the new curriculum requires assessment, which was not previously required. The current data was collected during a crucial time period when the introduction of assessment was announced but before any recommendations for processes for assessment were published. The revised curriculum provides that assessment of the special subject of moral education be implemented in all school classes, not only during moral education classtime. The phraseology seems to indicate that this consideration applies to assessment. Some data were collected in the weeks following publication of some principles that will inform assessment. However, as stated above, only one participant had actually read the document prior to interview.

There was a feeling of uneasiness (fuan) amongst teachers, expressed by a majority of participants responding to the idea of assessment. Initially, teachers see any summative aspect of assessment of moral education as pedagogically inappropriate for moral education. Further themes considered how moral education might be assessed quantitatively or qualitatively, and the ability of teachers to assess attitudes or behaviour outside the moral education classroom.

Participants discussed the extent to which the target of assessment (values, empathetic reasoning, or even love of nation) is hidden behind behaviour. For example, the intention or will to act may be the subject of learning, but may be undermined by the external motivation of assessment. Students may perform to the test.

"It is a feeling in the heart, so writing is OK. But testing..."

"If graded, they will not write what is really in their hearts."

This concern suggests that assessment is not appropriate for moral education because values cannot be expressed through declarative knowledge or 'getting the right answer'. On the other hand, the critique appears particularly levelled toward quantitative assessment, giving a grade in the form of a letter or number, rather than its summative nature, as teachers articulated possible means of conducting summative assessment in moral education, even whilst explaining that it is not ideal: "well, if it were not graded (tensūka)."

This perspective appears to mirror the argument made by Ahsan and Smith (2016) that qualitative classroom assessment should be the preferred mode of assessment if the

emphasising the need to balance pedagogy with democratic community involvement (2013, pp. 56975). 
following assumptions are accepted: that (1) learning is the goal of education and (2) social construction underpins learning. Japanese teachers have a tendency toward these beliefs (Bamkin, 2016 in moral education; and more generally Lewis, 1995; Cave, 2007; 2016). The wide support for educational time invested in social and emotional development may further increase the particular belief that qualitative assessment is more appropriate for moral education.

Formative qualitative feedback is already widespread in teaching practice. Many respondents discussed the qualitative assessment already practiced in class. One such example is assessing reflective sentences written by students at the end of many moral education lessons on 'what I didn't know before' and 'how I will change what I do'. A second example is marking worksheets, providing written comments in response to in-class work, discussions, activities, etc., decided upon by the class teacher. Some participants speculated that teacher comments in response to reflections on the class could be translated into a summative form, for example by copying them onto a different document with reference to learning outcomes. The concern was about creating more work, or fragmenting the feedback into modular units detracting from its pedagogic effectiveness. However, these concessions appeared minor enough to accommodate summative assessment without detracting from established institutional practices.

The subject leader for moral education at one elementary school suggested ways in which current practices may be leveraged or 'relabelled' to fulfil the requirements of assessment:

"All children [currently] keep a diary over the weekends. They choose a theme, and teachers occasionally comment, so they can understand how the child acts or are thinking outside of class. Teachers can encourage or offer advice - they mostly focus on positive things and say 'wonderful', 'keep it up!'”

Another teacher provided the same example at a different school, focusing on the perception that comments may need to be re-read by the teacher and repeated or condensed on a report card:

"This [means of] assessment is similar to what teachers already do. But it will be written down, so it will take more time."

These were presented as ways to potentially fulfil the requirement of assessment by continuing existing practices in a modified form.

As a separate argument, many teachers vocalised thoughts on what aspects of children's lives teachers can monitor, further reinforcing the perception that moral education is aimed toward practice in life inside the school, outside the school and on the boundaries between the two.

"We can assess role-plays, but not actual everyday behaviour."

"Teachers see playing, volunteering, sports, but not really everything."

"Assessment is difficult because behaviour is outside of school."

The extent to which behaviour can be seen is a more immediate concern for teaching professionals at junior high school. This is because each subject is taught by a subject specialist at junior high school so the homeroom/moral education teacher is in less contact 
with students in a narrower set of activities. ${ }^{9}$ Moreover, if assessment is confined to the activities of moral education classtime, the former concern of 'teaching to the test' becomes far more pertinent. Nonetheless, extending the scope of moral education beyond moral education classtime detracts from established institutional practices.

The region ku-2 has rewritten the moral education curriculum to include learning outcomes that describe observable behaviour rather than values and attitudes (Shinagawa, 2006). During observations, sixth grade students at one school were routinely asked during homeroom time for examples of nice things they had done over the weekend, and things they could have done better. These classes kept a whiteboard to tally the nice things students of the class had done. This does not appear to be well-established practice beyond this school, but represents an additional example to enable teachers to 'observe' behaviour outside of class.

Structurally, as alluded to above, the requirement of assessment may seek to undermine efforts by teachers and school administrators to exercise autonomy to reduce the patriotic content envisaged by the policy. Taylor argues that accountability tools rely on local structures of management but operate in reference centralised targets. Whereas local initiatives through teacher evaluation (Katsuno, 2016) may strengthen state control, headteachers and local Education Officers largely share beliefs that do not accord with nationalism in moral education. Headteachers may be co-opted by incentives driven by centralised targets, which may be a latent aim of introducing assessment. Indeed, the drive toward patriotic education ultimately originates not at MEXT, but the Council for Rebuilding Education, established in the Cabinet Office. However, central monitoring of performance is only realistically possible with quantitative data, which requires grading of assessment.

Guidance on the structure of assessment is within the remit of MEXT, who have not traditionally supported testing as an accountability tool, and have not made apparent a particular autonomous commitment to the strengthening of patriotic education in moral education. Furthermore, MEXT may take greater account (to an extent) of pedagogic arguments advanced by teachers and other education professionals.

Despite convincing arguments demonstrating that global education policy (Smith, 2014) and broader aspects of educational policy in Japan (Nitta, 2008) are moving toward an accountability model that requires disaggregated quantitative test data, there are counterexamples in recent education reform in Japan. For example, a new subject (Integrated Studies) was introduced without strict guidance or assessment, requiring teaching staff at schools to develop the content. One participant at MEXT suggested that current thinking on assessing moral education included worksheets such as those discussed above, and additionally portfolio-based assessment. Although a longer portfolio could be assessed using rubrics or criteria that include a number of learning outcomes, there are too many values listed in the curriculum to include each year under the current curriculum (MEXT, 2015a). More likely, the subheading 'relationship to wider society' would be used, if a rubric were required.

\footnotetext{
${ }^{9}$ Currently, non-subject classtime such as moral education is generally taught by the homeroom teacher. There is currently no indication that a specialist teacher, other than the homeroom teacher, will be required to teach moral education under the current reforms.
} 


\section{Summary}

This study examines the role of educational practitioners in mediating the implementation of the 2015 reforms of moral education. The nationalist agenda and strengthening of moral education has built upon the revised Fundamental Law of Education to reassign moral education as a special subject, entailing inclusion of moral education in the ministerial textbook approval system and assessment, to be implemented in the years leading up to 2018/19. Situated research in schools and classrooms is important to understand the education received by children in Japan, in the absence of previous work on moral education practice, neither in response to the 2015 reforms nor in general. This preliminary analysis considers educators' projections of future practice, supported by observations and previous literature on institutional beliefs and practices.

Educators are opposed to nationalism, which they see as the purpose and motivation behind the 2015 reforms of moral education. Although patriotism is not a day-to-day concern for educators, ideological opposition is apparent in responses whilst teaching promoting love of nation was not directly apparent. On the other hand, aspects of tradition and love of region (localism) continue as strong institutional practices in schools in Japan. Currently, teachers avoid nationalistic content, drawing on coursebooks creatively and selectively.

Institutions incorporate systematic processes of learning which can be relatively isolated from outside influence. In education, shared practices and beliefs resistant to nationalism appear to be transmitted through horizontal and vertical relationships. This provides an explanation for how shared beliefs and practices arise, including those concerning nationalism. Charting the movements and vehicles that contributed to this particular belief or practice (such as the activities of the JTU, of university or government affiliates, or massmedia discourse more widely) would require a historical analysis beyond the scope of this contemporary study.

Teachers already use textbooks adopted by the school or prefecture in many subjects, so many feel that little will change by adopting slightly different texts. However, previous research has shown that prefectural adoption procedures, if not ministerial approval procedures, can influence textbook content (Cave 2013). It is likely that teachers are aware of these changes, but believe that their ability to utilise a textbook 'creatively' and selectively will continue. The current research has provided further examples reiterating the capacity of teachers to re-focus content. Although this represents a move toward state control, at least where accountability tools are marshalled effectively, teachers enact policy partly as street level bureaucrats.

Teachers' uneasiness about assessment is pedagogical. There is concern about the appropriateness of summative assessment for moral education, and whether its aims can be observed or quantified. However, teachers will accommodate potentially onerous summative assessment for moral education once set by MEXT, insofar as it does not conflict with established practices. In combination with textbooks, assessment has a latent potential to strengthen state control of education, brining local management structures to bear and reducing the ability of teachers to mediate policy. However, there is no indication thus far of the quantitative data needed to invoke centralised targets. 
Previous ethnographic studies have detailed processes by which teachers appropriate and incorporate reform programmes into current practice, 'adopting the program to their own concerns in ways that [are] sometimes close to its original curriculum intention, and sometimes very far from them' (Cave, 2016, p. 271; also see Bjork, 2016, p. 199). Opposed to aspects of the reforms, teachers are acting as 'street bureaucrats' working within a strong institutional context. For this reason, there is likely to be strong cohesion in the response which will work to weaken or even subvert the intention of assessment.

To expand a quotation used above, Cave found that teachers have agency in enacting the requirements of education reform:

"to a significant extent, the content of the program [of integrated studies] amounted to existing activities, sometimes in an elaborated form, which had been given a new label. Schools thus appropriated integrated studies rather than simply implementing it, adopting the program to their own concerns in ways that were sometimes close to its original curriculum intentions, and sometimes very far from them" (2016, p. 221) However, both Cave and Bjork found teachers amenable to some fundamental aims of integrated studies as a program for realising 'relaxed education'. The current reforms to moral education are different in being overwhelmingly met with opposition, or even hostility, amongst educators. These beliefs are created and reproduced in educational institutions, which resonates amongst teacher educators and some local government officers.

It is unlikely that moral education practice will change with any pace as an immediate result of these policy reforms. The undeniable trend of central policy promoting patriotic content fostering a 'love of nation', which prompted fierce media and academic debate, may not materialise soon. The potential to avoid patriotic content may be possible in the medium term depending upon local conditions, such as the makeup of the local board of education and school leadership. Moreover, further investment in this agenda by MEXT or other arms of government could establish further accountability tools to reduce teacher autonomy to mediate policy. Already, teachers recognise the latent potential of the control over textbooks and perhaps assessment to pressure compliance if restructured as a controlling accountability tool. Nonetheless, this would require a rationalisation of content and quantification of assessment. Successful reform is more likely to emerge in dialogue within a body of professionals, which seems currently unlikely in the case of patriotism in moral education. In the longer term, the implementation of policy may depend upon the ideological position of MEXT. 


\section{Reference list}

Abe, S. (2006) Utsukushii kuni-e [Toward a beautiful nation]. Bushun Shinsho.

_ (2012) Abe-naikakusōridaijin shūnin kishakaiken [Prime ministerial inauguration press conference]. <http://www.kantei.go.jp/jp/96 abe/statement/2012/1226kaiken.html>.

Adler, P.A. \& Adler, P. (1987) Membership roles in field research. Newbury Park: Sage.

Ahsan, S. \& Smith, W.C. (2016) Facilitating student learning: a comparison of classroom and accountability assessments; in W. C. Smith (ed) Global testing culture: shaping education policy, perceptions and practice. Oxford: Symposium, pp. 131-151.

Anzai, S. (2015) Re-examining patriotism in Japanese education: analysis of Japanese elementary school moral readers. Educational Review, 67(4), pp. 436-458.

Ball, S. (1994) Education reform: a critical and post-structural approach. Buckingham: Open University Press.

Bamkin, S. (2016) Moral education at Japanese elementary school. London: WCMT.

Bjork, C. (2016) High stakes schooling. Chicago: University of Chicago Press.

Cave, P. (2007) Primary School in Japan: self, individuality and learning in elementary education. London: Routledge.

__ (2013) Japanese colonialism and the Asia-Pacific war in Japan's history textbooks. Modern Asia Studies, 47(2), pp. 542-80.

(2016) Schooling Selves: Autonomy, Interdependence, and Reform in Japanese Junior high school. Chicago: University of Chicago Press.

Dore, R. (1965) Education in Tokugawa Japan. London: Routledge.

Gold, R. L. (1958) Roles in sociological fieldwork. Social forces, 36, pp. 217-23.

Fundamental Law on Education (Act No. 120, Dec 22, 2006).

Hendry, J. (1986) Becoming Japanese: The World of the Pre-School Child. Honolulu: University of Hawai'i Press

Hoffman S. (1999) School texts, the written word and political indoctrination: a review of moral education curricula in modern Japan (1886-1997). History of Education, 28(1), pp. 87-96.

Katsuno, M. (2016) Teacher Evaluation Policies and Practices in Japan: How Performativity Works in Schools. London: Routledge.

Kaizuka, S. (2009) Dōtoku Kyōiku no Kyōkasho [Moral education textbooks]. Tokyo: Gakujustu Shuppankai.

Khan, Y. (1997) Japanese Moral Education Past and Present. Cranbury: Associated University Presses.

LDP (2012) LDP Jūten seisaku [manifesto] 2012. Jimintō. Available online $<$ http://jimin.ncss.nifty.com/pdf/seisaku ichiban24.pdf>. (2014) LDP Jūten seisaku-shū [manifesto] 2014. Jimintō. Available online $<$ http://iimin.ncss.nifty.com/pdf/news/policy/126585 1.pdf>.

Lewis, C. (1995) Educating hearts and mind. Cambridge: CUP.

Lipsky, M. (1983) Street level bureaucracy. New York: Russell Sage.

Matsuno, O. (1997) Kindai-nihon-no kōmin-kyōiku [Citizenship education in contemporary Japan]. Nagoya, University of Nagoya Press.

McLaughlin (1987) Learning from experience: lessons from policy implementation. Education evaluation and policy analysis, 9(2), pp. 171-78.

MEXT (2008) Gakushūshidōyōryō [School curriculum]. Tokyo: MEXT. Available online $<$ http://www.mext.go.jp/component/a menu/education/micro detail/ icsFiles/afieldfile/20 10/11/29/syo.pdf>. 
- (2014) watashi-tachi-no dōtoku. Tokyo: MEXT.

(2015a) Shōgakkō gakushūshidōyōryō [Elementary school curriculum as amended].

Available online <http://www.mext.go.jp/a menu/shotou/new-

cs/youryou/ icsFiles/afieldfile/2015/03/26/1356250 1.pdf>.

- (2015b) Shōgakkō gakushūshidōyōryō kaisetsu: tokubetsu-no kyōka dōtokuhen

[Curriculum guidance for elementary school: Dotoku special subject].

Muta, H. (2006) Trends and issues in deregulation and decentralization of educational administration in Japan; in C. Bjork, Educational Decentralization Asian Experiences and Conceptual Contributions. Dordrecht: Springer, pp. 97-113.

Nakayasu, C. (2016) School curriculum in Japan. The curriculum journal, 27(1), pp. 134-150.

NHK (2013) Yae-no sakura. DVD. dir. Taku Kato and others.

Nitta, K. (2008) The politics of structural education reform. London: Routledge.

Nippon Kaigi (2016) Nippon kaigi-ga tokuteki-suru mono-no [Objectives of Nippon Kaigi]. $<$ http://www.nipponkaigi.org/about/mokuteki>.

Okada, A. (2002) Education of whom, for whom and by whom? Revisiting the fundamental Law of Education in Japan. Japan Forum, 14(3), pp. 425-441.

Peak, L. (1991) Learning to Go to School in Japan: The Transition from Home to Preschool Life. Berkeley: University of California Press.

Roesgaard, M. (2011) 'The ideal citizen', globalisation, and the Japanese response: risk, gate-keeping, and moral education in Japan; in D. Willis and J. Rappleye (eds)

Reimagining Japanese Education: Oxford: Symposium, pp. 171-191.

Roesgaard, M. (2016) Moral Education in Japan: Values in a global context. London: Routledge.

Shinagawa Ward Board of Education (2006 1st ed) Shiminka: shidō-no hibiki. Tokyo: Kyōiku shuppan.

Smith, W. C. (2014) The global transformation toward testing for accountability. Education policy analysis archives. 22, p. 116.

Taylor, I. (2007) Discretion and control in education: the teacher as street-level bureaucrat. Educational management administration and leadership, 35(4), pp. 555-572.

Takayama, K. (2011) Reconceptualising the politics of Japanese Education; in C. Willis \& J. Rappleye (eds) Reimagining Japanese Education. Oxford: Symposium, pp. 247-280.

Tsuneyoshi, R. (2001). The Japanese Model of Schooling: Comparisons with the United States. New York: RoutledgeFalmer.

Wray, $\mathrm{H}$. (2000) The fall of moral education and the rise and decline of civics education and social studies in occupied and independent Japan. Japan Forum, 12(1), pp. 15-41.

Yamazumi, M. (1986) Educational democracy vs state control; in G. McCormack \& Y. Sugimoto (eds) Democracy in contemporary Japan. London: Routledge, pp. 90-112. 